\title{
Crude Reality
}

\author{
Adam Rome
}

Oil is the elephant in every room in modern American history. From the consumer-culture room to the politics room, the labor room to the U.S.-and-the-world room, oil is right there, as big as Texas, yet hardly anyone notices. That is less true than it used to be. The Journal of American History even devoted a special issue to oil in 2012. Yet modern American historians still have not thought enough about "crude reality."1

I'm no exception. Because I'm an environmental historian, I've always understood that energy was critically important. But I was slow to rise to the revisionist challenge: How would reckoning with oil change our scholarship?

I first reflected on the invisibility of oil when I was an assistant professor. In a 2002 essay about what really matters in modern American history, I chided the editors of a well-regarded volume on that subject for ignoring the petroleum revolution. In 1900, I wrote,

[O]il still was a relatively small part of the American economy-but, in the next fifty years, oil became the nation's principal source of energy. Oil also became a basic ingredient in the manufacture of thousands of products, including plastics, agricultural chemicals, and clothing. The rise of the oil economy had profound consequences. The production and consumption of oil contributed to almost all of the most pressing environmental problems of the twentieth century. In countless ways, the ability to use a powerful and cheap source of energy transformed daily life-what we eat, where we live, how we work, and what we do for fun. The rise of the oil economy also changed many of the structures of American society. Without some understanding of the history of energy use, scholars and students cannot truly comprehend the depopulation of rural America, the spread of suburbia, the emergence of the Sun Belt, or the unprecedented affluence of the decades after World War II. The list could go on. ${ }^{2}$

Despite my strong words, I didn't revise my course syllabi to make oil more central. In my upper-level class on U.S. history from 1945 to 1988, for example, I only discussed oil in lectures on the foundations of the postwar economic boom, the rise of the environmental movement, and the fading economy of the 1970s. In retrospect, that seems seriously inadequate.

But giving oil its due in 2002 would have required a lot of digging. The historical literature was limited. In my essay on what matters in modern American history, I cited just three pioneering books about energy: Martin Melosi's Coping with Abundance, James Williams's Energy and the Making of Modern California, and David Nye's Consuming Power. Now the scholarly

\footnotetext{
${ }^{1}$ The special issue, edited by Brian C. Black, Karen R. Merrill, and Tyler Priest, is "Oil in American History," Journal of American History 99, no. 1 (June 2012): 19-255, cited hereafter as OiAH. It is available free online with additional features: http://archive.oah.org/special-issues/oil/contents/index.html. I borrow the phrase "crude reality" from Brian C. Black, Crude Reality: Petroleum in World History (Lanham, MD, 2012).

${ }^{2}$ Adam Rome, "What Really Matters in History? Environmental Perspectives on Modern America," Environmental History 7, no. 2 (April 2002): 303-18, here 303-4.

(C) The Author(s) 2018. Published by Cambridge University Press
} 
literature is richer, though still not rich enough. Journalists also have added to our understanding of oil's importance. ${ }^{3}$

I see now that oil shaped many of the major political developments of the twentieth century. The beginning of the story is not news. In the Progressive Era, muckrakers made Standard Oil the archetype of the threat of monopoly, and the company's chokehold on the refining industry spurred the antitrust legislation of the period. But scholars are just beginning to acknowledge the importance of oil in the rise and fall of the New Deal order. As several journalists have shown, oil also fueled the growth of the far right. ${ }^{4}$

The great mission of the Democratic Party in mid-century was building a massconsumption economy, and that project was predicated on cheap oil. Cheap oil meant cheap food, cheap housing, cheap clothes, cheap vacations-well, cheap everything. The unprecedented abundance of energy after World War II also allowed policy makers to envision endless economic growth. But the oil crisis of the 1970s undermined the effort to ensure an evergrowing middle class. For the first time, inflation and unemployment both rose, and key constituents of the New Deal coalition suffered most. Because stagflation proved so intractable, the oil crisis cast doubt on government's ability to improve the lives of ordinary people (Figure 1). ${ }^{5}$

Before and after the 1970s, oil money strengthened the conservative challenge to liberalism. In the early 1950s, Texas oil tycoon H. L. Hunt created a right-wing radio, television, and print network that became a principal booster of Senator Joseph McCarthy. He later established another network to promote Christian conservatism. William F. Buckley's National Review also had oil backing. In recent decades, Charles and David Koch-the heads of a privately held industrial conglomerate rooted in oil refining and transport-have become the most powerful supporters of the libertarian and Tea Party movements. The Kochs have created a vast infrastructure of think tanks, lobbying organizations, and "dark money" funders of political candidates committed to shrinking government at all levels. Their efforts have gone hand-in-hand with those of many other energy magnates. ${ }^{6}$

The conservatism of the oil titans was not just a function of wealth. The hit-or-miss nature of the industry encouraged an evangelical individualism. Wildcatters were convinced that their risk-taking exemplified the virtues of capitalism, and they resented any effort to limit their freedom. With the rise of the environmental movement, antigovernment sentiment in the oil patch became even more intense. The air and water pollution legislation of the 1970s directly challenged the industry-and so do proposals to mitigate the hazards of climate change. According to journalist Jane Mayer, Koch Industries especially has a history of egregiously and willfully flouting environmental laws. The Kochs's "philosophical opposition" to regulations, she concluded, is hard to separate from their "financial interest in avoiding them."7

\footnotetext{
${ }^{3}$ Martin V. Melosi, Coping with Abundance: Energy and Environment in Industrial America (Philadelphia, 1985); James C. Williams, Energy and the Making of Modern California (Akron, OH, 1997); David E. Nye, Consuming Power: A Social History of American Energies (Cambridge, MA, 1998).

${ }^{4}$ For a summary of the demonizing of Standard Oil, see Black, Crude Reality, 73-7.

${ }^{5}$ Brian C. Black, "Oil for Living: Petroleum and American Conspicuous Consumption" OiAH, 43-6; Timothy Mitchell, Carbon Democracy: Political Power in the Age of Oil (London, 2011), 139-40; Meg Jacobs, Panic at the Pump: The Energy Crisis and the Transformation of American Politics in the 1970s (New York, 2016), 9, 211, 269. Lizabeth Cohen also argues that the 1970s undermined the mass-consumption project, though she puts less emphasis on the rise in oil prices. See A Consumers' Republic: The Politics of Mass Consumption in Postwar America (New York, 2003), 388-9.

${ }^{6}$ Bryan Burrough, The Big Rich: The Rise and Fall of the Greatest Texas Oil Fortunes (New York, 2009), 204, 2224, 276; Jane Mayer, Dark Money: The Hidden History of the Billionaires Behind the Rise of the Radical Right (New York, 2016).

${ }^{7}$ Darren Dochuk, "There Will Be Oil: A Sacred History of Energy and the Environment in the Modern United States," Organization of American Historians Distinguished Lecture, http://www.oah.org/lectures/lecturers/view/ 1705 (accessed May 31, 2017); Darren Dochuk, "Blessed by Oil, Cursed by Crude: God and Black Gold in the American Southwest," OiAH, 59; Mayer, Dark Money, 15-16, 87, 123-8, 200-3, 275, with the quotations from 123.
} 


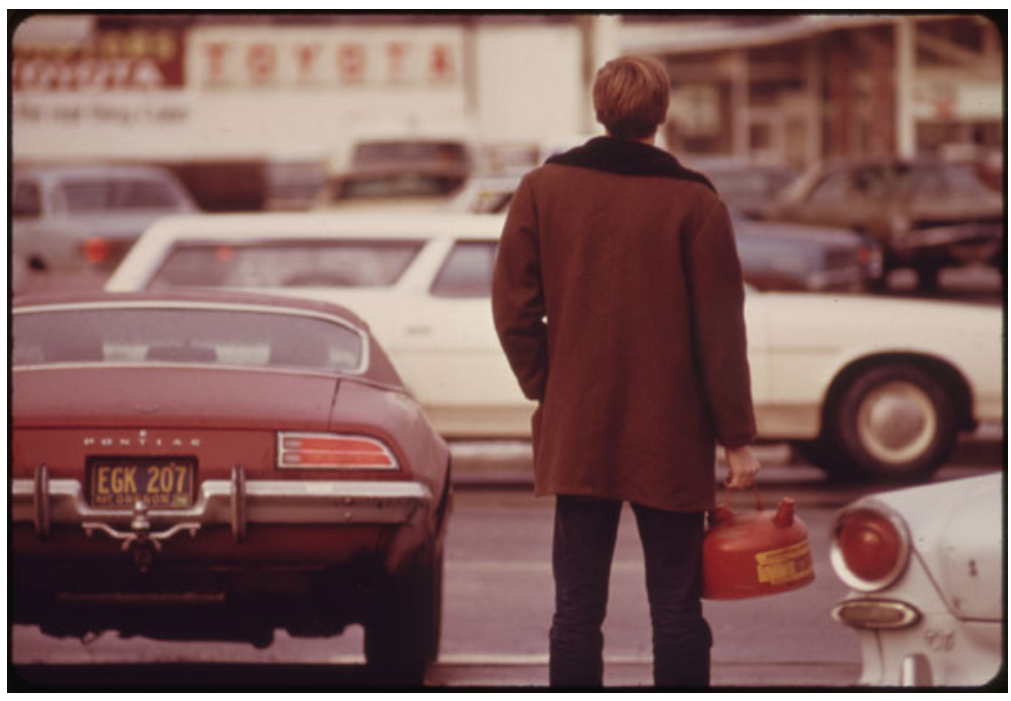

Figure 1. David Falconer's image of a stranded driver in a gas line in 1973 illustrates the one oil story that almost everyone knows. But the oil crises of the 1970s should be just the beginning of our reckoning with crude reality. National Archives at College Park - Still Pictures (RDSS), 412-DA-13008.

I also see more clearly now the importance of oil in making "the American century." The U.S. produced almost two-thirds of the world's oil in 1920 and more than two-thirds in 1940. That was a huge advantage in World War II. Americans had surplus capacity that could go to military purposes at home and abroad, including the production of synthetic rubber. The ability to tap vast reservoirs of oil also shaped the nation's strategy in the early decades of the Cold War. ${ }^{8}$

In 1970, however, U.S. oil production peaked. Imports rose in just a few years to more than 35 percent of total consumption. The Arab embargo of 1973 drove home the new precariousness of Americans' oil economy. The presidents of the 1970s all tried and failed to promote energy independence, and access to foreign supplies became a national-security issue. Jimmy Carter acknowledged the strategic importance of Middle Eastern oil after the Soviet Union invaded Afghanistan: "An attempt by any outside force to gain control of the Persian Gulf region will be regarded as an assault on the vital interests of the United States of America," he declared in 1980, "and such an assault will be repelled by any means necessary, including military force." Carter's successors extended that doctrine. The protection of Kuwaiti oil fields was an explicit justification for Operation Desert Storm in 1991, and the U.S. continues to maintain a major military force in the Gulf. ${ }^{9}$

As the appointment of ExxonMobil CEO Rex Tillerson as secretary of state makes clear, the United States long has exercised influence in the world as much through business activity as state policy, and oil companies have been especially transformative. ExxonMobil alone has prospected in more than twenty nations. The company's Washington, DC office is like an embassy, journalist Steve Coll argued in Private Empire, and its CEO travels the world like a head of state or a foreign minister. ExxonMobil was embroiled in a civil war in Indonesia. It has undertaken nation-building and social engineering projects in other countries. Everywhere

\footnotetext{
${ }^{8}$ David S. Painter, "Oil and the American Century," OiAH, 25-9; Tyler Priest, "The Dilemmas of Oil Empire," OiAH, 236.

${ }^{9}$ Jacobs, Panic at the Pump, with the quotation on 251; Donald Worster, Under Western Skies: Nature and History in the American West (New York, 1992), 199. In addition, see Priest, "The Dilemmas of Oil Empire," 236-51; Toby Craig Jones, “America, Oil, and War in the Middle East," OiAH, 208-18.
} 
American oil companies have operated, they have had far-reaching social and political impact. Indeed, oil development often is a prime example of the "resource curse"-the baleful effect of sudden wealth on underdeveloped societies. ${ }^{10}$

Some of the topics I mentioned in 2002 also are more central than I realized then. Plastic is the best example. Though hardly anything was made from plastic in 1945, the new materials became a foundation of the mass-consumption economy. Plastic allowed manufacturers to produce and distribute goods more cheaply. Because plastic cost so little, many luxuries became affordable. The cheapness of plastic also encouraged people to throw more stuff away, and the endless cycle of buying and discarding kept the postwar economy booming. Now we are surrounded by plastic-toys, chairs, bottles, bags, credit cards, tools, microwave trays, sneakers, computers, shower curtains, eyeglasses, fleece sweatshirts, vacuum cleaners, doormats, toothbrushes, car interiors. As journalist Susan Freinkel argued, "We all live in Plasticville.""

That means reckoning with plastic is essential to understanding the complexities of modern consumer culture. Plastic provoked debates about class and taste. It promised widespread affluence, even democratic stylishness - and yet, to many highbrow critics, it epitomized schlock and second-rate utility. Plastic inspired passive consumption. In the words of historian Susan Strasser, "Nobody made plastic at home, hardly anyone understood how it was made, and it usually could not be repaired." Yet that passivity was tied to a heady feeling of freedom: Plastic required little care. Though seemingly inexpensive, plastic in fact came at considerable social and environmental cost. The petrochemical corridor of the Gulf Coast is the textbook example of environmental injustice, because the poor disproportionately bear the toxic burden of plastic manufacturing. Plastic also has fouled the oceans, filled landfills, and threatened the health of consumers. ${ }^{12}$

One more example-work. "Abundant energy turned labor-intensive jobs into capitalintensive ones," Martin Melosi argued in Coping with Abundance, and that shift had radical consequences. The most obvious is the depopulation of the countryside. The U.S. had thirty million farmers in 1940, but now the number is barely one-tenth of that total-and only 300,000 farmers account for roughly 90 percent of farm production. Fossil fuels were a key part of that decline: Oil-powered machinery and chemicals derived from oil and natural gas revolutionized agriculture in the mid-twentieth century. Indeed, some critics argue that modern agriculture really is "petrofarming." 13

Oil also reshaped labor politics. When coal was king, the United Mineworkers was one of the nation's most powerful unions, and that power came partly from the concentrated nature of underground mining. But oil-field development was very different. It did not require an army of laborers, and the work was itinerant. Early on, oil-field workers could dream of

\footnotetext{
${ }^{10}$ Steve Coll, Private Empire: ExxonMobil and American Power (New York, 2012). For a more sympathetic view of Exxon's overseas impact, see Joseph A. Pratt, "Exxon and the Control of Oil," OiAH, 152-3.

${ }^{11}$ Susan Freinkel, Plastic: A Toxic Love Story (Boston, 2011), 1. For the benefits of plastic in manufacturing, see Robert J. Gordon, The Rise and Fall of American Growth: The U.S. Standard of Living Since the Civil War (Princeton, NJ, 2016), 561. The historical literature on plastic has not advanced much beyond Jeffrey L. Meikle's pioneering American Plastic: A Cultural History (New Brunswick, NJ, 1995).

${ }^{12}$ Susan Strasser, Waste and Want: A Social History of Trash (New York, 1999), 267. Freinkel offers rich insight into the conflicting aesthetics as well as the environmental costs of plastic. See Plastic, 28-51, 81-202. Jennifer Price has a provocative discussion of class, taste, and pink flamingos in Flight Maps: Adventures with Nature in Modern America (New York, 1999), 111-65. For the hazards of life in the petrochemical communities of the Gulf Coast, see Craig E. Colten, "An Incomplete Solution: Oil and Water in Louisiana," OiAH, 92-8; Barbara L. Allen, Uneasy Alchemy: Citizens and Experts in Louisiana's Chemical Corridor Disputes (Cambridge, MA, 2003); Steven Lerner, Diamond: A Struggle for Environmental Justice in Louisiana's Chemical Corridor (Cambridge, MA, 2004).

${ }^{13}$ Melosi, Coping with Abundance, 9; Paul K. Conkin, A Revolution Down on the Farm: The Transformation of American Agriculture Since 1929 (Lexington, 2008), 3; Amory B. Lovins, L. Hunter Lovins, and Marty Bender, "Energy and Agriculture," in Meeting the Expectations of the Land: Essays in Sustainable Agriculture and Stewardship, eds. Wes Jackson, Wendell Berry, and Bruce Colman (San Francisco, 1984), 68-86, here 70-5.
} 
escaping the working class by becoming wildcatters. That made them unlikely to organize. Though refinery workers sometimes struck, their union never fundamentally challenged the nation's ruling classes. The transport of oil required far fewer workers than coal, because oil often flowed to market through pipelines. For all those reasons, political theorist Timothy Mitchell concluded that the shift from coal to oil made democratic politics more difficult to sustain. Historian Shane Hamilton made a similar argument about the rise of trucking. Many truck drivers were ideologically closer to farmers than railway workers: They owned their rigs, and they prided themselves on their independence. The new trucking economy thus helped move the country rightward. ${ }^{14}$

Of course, nothing in the history of oil was inevitable. Since my 2002 essay, a handful of scholars have shown that market forces alone cannot explain our dependence on oil. As Paul Sabin argued in Crude Politics, "Abundance was made as much as discovered," and government was critical in that process. State and federal officials allowed oil exploration on public lands, gave the industry huge tax breaks, and controlled production to prevent "wasteful" exploitation of oil fields. That direct encouragement was just the start. The dominance of cars, trucks, and container ships all depended on public as well as private decisions. Gasoline taxes were especially important: Though invisible to consumers, they became a perpetual-motion machine for funding endless highway construction. The ubiquity of plastic also resulted partly from government action. During World War II, federal officials encouraged the chemical industry to invent plastic substitutes for strategic materials, and after the war companies sought to turn the new synthetics into consumer products. ${ }^{15}$

The recent work on the political economy of oil brings me back to the revisionist challenge. To do justice to crude reality, we cannot simply pay more attention to a few momentous, yet neglected, changes. We need to rethink how we approach the past. Environmental historians have done the most so far to explain how and why oil remade the nation. But a thorough understanding of oil's historical significance requires the insights of other specialties that now are marginal or secondary-agricultural history, the history of technology, and business history, especially. It requires more work on the relationship between politics and economics. ${ }^{16}$

The study of material culture also is key. Several journalists have pointed the way. To tell the story of plastics, Susan Freinkel considered the histories of eight simple objects, from combs to disposable lighters. Amanda Little's popular history of energy, Power Trip, began with a question drawn from everyday life: What made oil so pervasive, so indispensable, so taken for granted ${ }^{17}$

If historians paid more attention to daily experience, oil would be central in modern American historiography. Again, that speaks to a bigger challenge for the profession. Our research agendas rarely focus on questions about the ways people lived in the past. We leave that realm to museum curators and nonfiction writers. As a result, our histories too often

\footnotetext{
${ }^{14}$ Mitchell, Carbon Democracy, 18-39; Shane Hamilton, Trucking Country: The Road to America's Wal-Mart Economy (Princeton, NJ, 2008). Thomas G. Andrews also makes a powerful argument about labor politics and the nature of mining in Killing for Coal: America's Deadliest Labor War (Cambridge, MA, 2008). For another view of refinery unions, see Tyler Priest and Michael Botson, "Bucking the Odds: Organized Labor in Gulf Coast Oil Refining," OiAH, 100-10. Christopher F. Jones analyzes the early history of pipelines in Routes of Power: Energy and Modern America (Cambridge, MA, 2014), 123-59.

${ }^{15}$ Paul Sabin, Crude Politics: The California Oil Market, 1900-1940 (Berkeley, CA, 2004), with the quotation on page 2; Joseph A. Pratt, “The Politics of Oil Revisited," Reviews in American History 36, no. 1 (March 2008): 77-83; Christopher W. Wells, "Fueling the Boom: Gasoline Taxes, Invisibility, and the Growth of the American Highway Infrastructure, 1919-1956," OiAH, 72-81; Hamilton, Trucking Country; Marc Levinson, The Box: How the Shipping Container Made the World Smaller and the World Economy Bigger (Princeton, NJ, 2006), 84-8, 93, 192-5, 237; Freinkel, Plastic, 6. In addition, see Christopher W. Wells, Car Country: An Environmental History (Seattle, 2012).

${ }^{16}$ For the relative rank of fields in the discipline, see Robert B. Townsend, "The Rise and Decline of History Specializations over the Past 40 Years," Perspectives on History 53, no. 9 (December 2015): 27-29.

${ }^{17}$ Freinkel, Plastic; Amanda Little, Power Trip: The Story of America's Love Affair with Energy (New York, 2009).
} 
are academic in the worst sense: They do not tell us enough about what it has meant to be human, so they do not appeal to readers beyond the guild. That is a loss, and not just for people interested in oil.

Adam Rome teaches environmental history at the University at Buffalo. A leading expert on the history of environmental activism, he is the author of the prizewinning The Bulldozer in the Countryside: Suburban Sprawl and the Rise of American Environmentalism (2001) and The Genius of Earth Day: How a 1970 Teach-In Unexpectedly Made the First Green Generation (2013). He also is co-editor of Green Capitalism? Business and the Environment in the Twentieth Century (2017). From 2002 to 2005, he edited the journal Environmental History. Since 2014, he has been an Organization of American Historians Distinguished Lecturer. 